\title{
Microbial Fuel Cell: An Efficient Method to Utilize Prokaryotic Potential to Engender Reliable Energy
}

\author{
Ankur $B^{1^{*}}$ and Shipra $\mathrm{S}^{2}$ \\ ${ }^{1}$ Department of Biotechnology \& Life Sciences, Institute of Biomedical Education \& Research, Mangalayatan University, India \\ ${ }^{2}$ Department of Biotechnology, RBS College, India
}

\begin{abstract}
A MFC (Microbial Fuel Cell), a microbial power module is a novel and exquisite advancement serving reasonable and green bio-vitality change innovation in the midst of microbial assimilation of regular acids and sugars. In commenced work twofold microbial operated energy chambers were constructed with diverged nature of microorganisms. In MFC-R1, E. coli (Escherichia coli) was utilized in anode slot while in MFC-R2, the sludge samples, anaerobically activated were exploited as anode and aerobically activated in cathode. The extreme yield of voltage was $150 \mathrm{mV}$ in MFC-R1 after adding glucose and $400 \mathrm{mV}$ in MFC-R2. In absence of appropriate air circulation in MFC-R1 voltage yield was diminished to $110 \mathrm{mV}$, while after proper aeration, the voltage yield has increased up-to $140 \mathrm{mV}$. In MFC-R2 voltage generation was reduced $(250 \mathrm{mV})$ in deficiency of airing and increased up-to $400 \mathrm{mV}$ after providing proper aeration. In MFC-R2, the higher voltage sustained for an extensive period (for 4 days) while in MFC-R1 voltage output declined after Day 1 . This may be happened because in MFC-R2, additional substrates (the sludge samples rich in biomass/nutrients) were present and diverse sorts of microbes may be grown under wild conditions (belonging to different genus/species/strains) to utilize that substrate. Subsequently, the MFCs are being produced for both waste management besides bio-electricity generation and what's more, the thought would be fiscally functional and cooperative ecologically.
\end{abstract}

Keywords: Microbial fuel cell; Cathode; Anode; Bio-electricity; Saltbridge; Bio-electrochemical system

\section{Introduction}

To determine an expanding worldwide request in energy, a wellspring of supportable and ecologically benevolent service is required. Energy derived from petroleum byproducts, sustainable and atomic sources, has negatively influenced the nature [1]. It takes coherently that utilizing petroleum derivatives has seriously endangered human life through its uncommon aftermaths, for example, an Earth-wide temperature boost and air contamination [2].

Be that as it may, numerous nations have attempted amazing endeavors to locate a pertinent answer for energy crises by turning towards sustainable power sources [3]. An eventual outcome of these endeavors, one hitherto proposed elective energy sources could be microbially operated fuel cells which produces electrical energy utilizing high esteem metal catalysts [4]. MFC practices lively microorganism in anode (anaerobic) compartment for making bioelectricity [5]. MFC's are equipped for changing over energy, accessible in a bio-convertible substrate, straightforwardly into electricity with the assistance of micro-organisms [5]. Fuel cells (Figure 1) operated microbially are innovative energy arrangements that utilizes bacterial cells to transform carbohydrates in anaerobically into free electrons and waste-stuff [6]. Free electrons stored by micro-organisms on anode side creates a potential variance among both (anode \& cathode) compartments yielding a 'MFC' $[7,8]$.

The conception of utilizing miniaturized organisms as impetuses in power devices was investigated amid 1970s [9]. In 1991, microbial energy chambers managing waste-water were presented [10]. Regardless, it has late explained that microbial energy units with an upgraded control yield were created giving conceivable opportunities towards functional applications [11]. Moreover, microbial energy units have pulled in developing consideration for their ability of electricity production and treating natural waste streams simultaneously [12].

\section{MFCs - A step ahead of traditional organizations}

It should be realized that an MFC is a form of hybrid system-very different from traditional aerobic or anaerobic systems. The microbes for fuel cell must be developed or grown anaerobically, remembering the ultimate objective of delivering power [13]. The strategy should be anticipated towards limiting oxygen spillage, predominantly across the cathode and proton exchanger membrane/salt bridge, for minimal occurring of aerobic action [14]. Regardless of whether oxygen leaks in anode chamber it is quickly devoured by the microscopic organisms producing a low redox potential [15].

In this work, fuel cell grounded on aerobic plus anaerobic stimulated sludge was constructed and efficiency of generated voltage was compared. The "graphite" was used to make electrode rods, glucose as carbon source, laboratory grown $E$. coli culture in anode section and aerobically initiated sludge in cathode slot following with salt bridge for cation exchange.

\section{Material and Methods}

\section{Experimental set-up: Microorganisms in MFCs}

It was found earlier that the organisms of municipal wastes are appropriate for MFC application [16]. The sort of microorganism to be

*Corresponding author: Ankur B, Department of Biotechnology \& Life Sciences, Institute of Biomedical Education \& Research, Mangalayatan University, India, Tel: 918475080995; E-mail: ankurphd995@gmail.com

\section{Received March 26, 2018; Accepted May 21, 2018; Published May 28, 2018}

Citation: Ankur B, Shipra S (2018) Microbial Fuel Cell: An Efficient Method to Utilize Prokaryotic Potential to Engender Reliable Energy. J Microb Biochem Technol 10: 69-75. doi: 10.4172/1948-5948.1000398

Copyright: $\odot 2018$ Ankur B, et al. This is an open-access article distributed under the terms of the Creative Commons Attribution License, which permits unrestricted use, distribution, and reproduction in any medium, provided the original author and source are credited. 
employed as a part of fuel cell relies upon what substrate is proposed to be oxidized. The microscopic organisms, for example, Geobacter sulfurreducens straight forwardly uptake acetic acid source yet can't deal with complex sugars [17]. Earlier, coordinate oxidizing of glucose and fructose by Rhodoferax ferrireducens (facultative anaerobe) has been accounted that can be wielded extensively in variety of conceivable applications $[18,19]$.

\section{Strategy for MFC construction \\ Electrodes in MFCs}

The anode materials utilized can significantly affect density (Figure 2). Anode electrodes are prepared characteristically from graphite constituents including plate, paper, felt, and foam [20]. The highly permeable materials have immense power density (Figure 2) because of which more intricate surface zone is accessible for microbial colonization. The power yield is emphatically associated to anode surface region [21]. The cathodic zone, interestingly, has just a minor impact on power output [22].

\section{Material for construction of MFCs}

Graphite rods (pencil lead purchased from co-operative store, AAIDU), Copper wire (DC wire purchased from local electrical shop), Milli-voltmeter (Make - Omega, purchased from Science Traders, Civil lines, Allahabad), Two food grade plastic flasks - $1 \mathrm{~L}$ capacity (purchased from local stationary shop), Air pump (Sobo Aquarium Pump, China purchased from Shanti aquarium, Bairahna, Allahabad), Conical flask, Beakers Petriplates, Culture tube, Volumetric flask (Borosil), Plastic
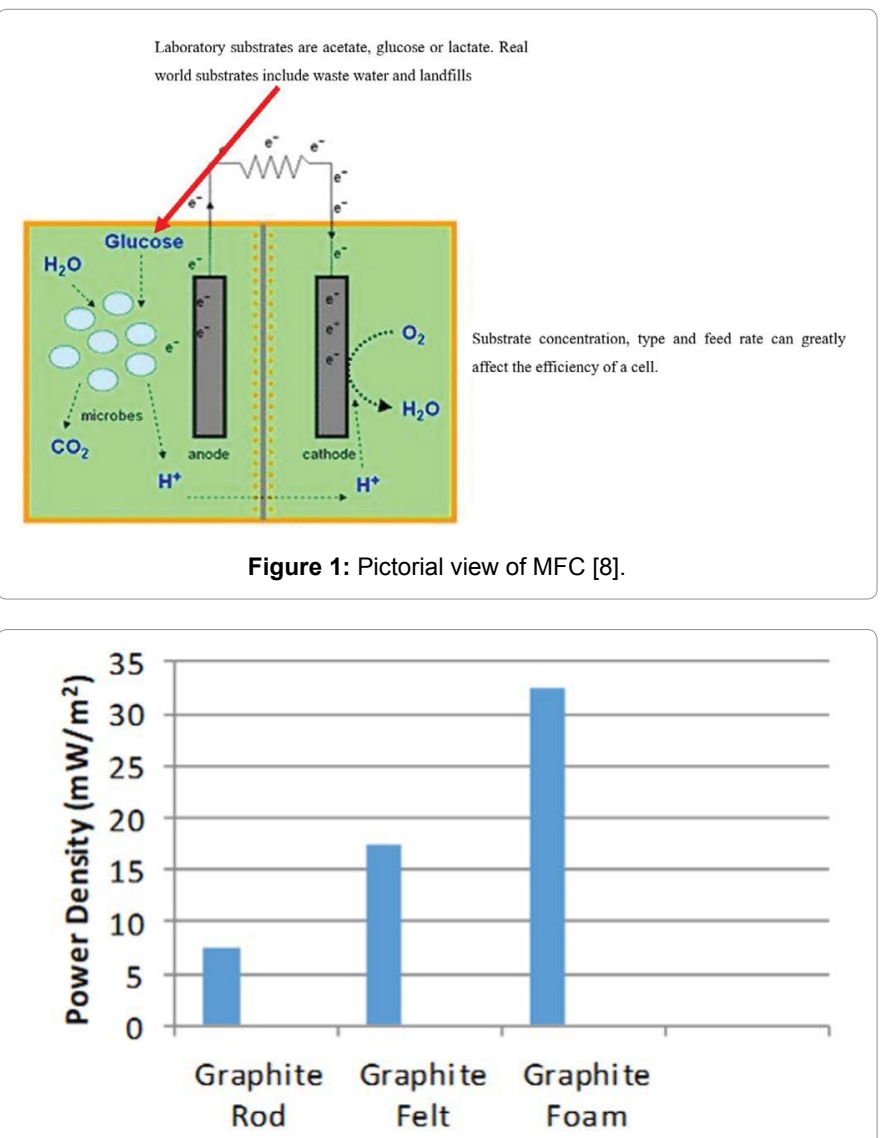

Figure 2: A comparison of three different graphite materials with all variables except electrode materials held constant [9] pipe of diameter $2.5 \mathrm{~cm}$ and length about $6 \mathrm{~cm}$ (domestic wiring pipe purchased from local electrical shop), Cello tape, M-Seal (purchased from stationary shop).

\section{Chemicals required}

The following chemicals were used during our work.

- Agar (SRL Pvt. Ltd.)

- $\mathrm{CaCl}_{2}$ (SRL Pvt. Ltd)

- Dextrose (Central Drug House Pvt. Ltd.)

- $\mathrm{FeCl}_{3} \cdot 6 \mathrm{H}_{2} \mathrm{O}$ (Qualigens Fine Chemicals)

- $\mathrm{KCl}($ SRL Pvt. Ltd.)

- $\mathrm{MgSO}_{4} \cdot 7 \mathrm{H}_{2} \mathrm{O}$ (MERCK Pvt. Ltd.)

- $\mathrm{MnSO}_{4} \cdot 7 \mathrm{H}_{2} \mathrm{O}$ (Central drug House Pvt. Ltd.)

- $\mathrm{NaHCO}_{3}$ (SRL Pvt. Ltd.)

- $\mathrm{NaHPO}_{4}$ (Thomas Baker Chemicals Ltd.)

- $\mathrm{Na}_{2} \mathrm{HPO}_{4}$ (Thomas Baker Chemicals Ltd.)

- $\mathrm{NH}_{4} \mathrm{Cl}$ (SRL Pvt. Ltd.)

- $\left(\mathrm{NH}_{4}\right)_{2} \mathrm{SO}_{4}$ (MERCK Pvt. Ltd.)

- Nutrient agar and broth (HiMedia)

\section{Microorganisms used}

Pure laboratory culture of Escherichia coli (Obtained from Department of Microbiology \& Microbial Technology, AAI-DU). Aerobic and along with Anaerobic activated sludge (collected from waste-water treatment plant of Ganga Pollution Control Board, Allahabad).

\section{Construction of salt-bridge}

The salt-bridge was made consisting 3\% agar (w/v) dissolved in $1 \mathrm{M}$ solution of $\mathrm{KCl}$. A plastic pipe was rinsed with $\mathrm{ddH}_{2} \mathrm{O}$ (double distilled water) and air dried. One end of pipe was sealed properly using cello tape. Further, $\mathrm{KCl}(7.5 \mathrm{~g})$ and $3 \mathrm{~g}$ of agar was dissolved in $100 \mathrm{ml}$ distilled water by continuous stirring. The warm mixture was carefully decanted into the plastic pipe avoiding the trap of any air bubble in the mixture. The mixture was then permitted to set inside the plastic pipe and after solidification cello tape was removed carefully from the sealed end.

\section{Procedure for assembly of MFC}

A puncture sufficient to oblige the salt-bridge scaffold, was cut at the side of both the plastic flasks. The salt-bridge was fixed and connected to both the plastic flasks by inserting the ends into the space made by puncturing the sides of plastic flasks. Finally, cavity between plastic pipe and the flask was sealed by epoxy (M-Seal). A minute perforation was made for the wire attached with electrode (graphite rods), on two caps of both the flasks. Another puncture in cathodic chamber was made for accommodating rubber tubing of air pump. The electrode wire was passed from the space created on the flask caps and was sealed. The pipe of air pump was passed from another hovel made on the lid of cathodic chamber. The flask behaving as anode was marked as "anode chamber" and other flask working as cathode was marked as "cathode chamber".

\section{Construction \& operational setup for MFCs}

\section{Preparation of MFC based on pure culture of $E$. coli}

MFC based on pure culture of $E$. coli was named as MFC-R1 and its preparation was completed by dissolving peptone $(6 \mathrm{~g})$, beef extract $(6$ 
$\mathrm{g}), \mathrm{NaCl}(10 \mathrm{~g})$ in $2 \mathrm{~L}$ of warm distilled water and $\mathrm{pH}$ was maintained at 7.3. This step was followed by further addition of $\mathrm{NaHCO}_{3}(4 \mathrm{~g}), \mathrm{NH}_{4} \mathrm{Cl}$ $(0.62 \mathrm{~g}), \mathrm{KCl}(0.26 \mathrm{~g}), \mathrm{NaHPO}_{4}(8.44 \mathrm{~g}), \mathrm{Na}_{2} \mathrm{HPO}_{4}(5.50 \mathrm{~g}),\left(\mathrm{NH}_{4}\right)_{2} \mathrm{SO}_{4}$ $(1.02 \mathrm{~g}), \mathrm{MgSO}_{4} .7 \mathrm{H}_{2} \mathrm{O}(0.4 \mathrm{~g}), \mathrm{CaCl}_{2}(0.03 \mathrm{~g}), \mathrm{FeCl}_{3} .6 \mathrm{H}_{2} \mathrm{O}(0.002 \mathrm{~g})$ and $\mathrm{MnSO}_{4} \cdot \mathrm{H}_{2} \mathrm{O}(0.04 \mathrm{~g})$ to the broth. From autoclaved broth $1 \mathrm{~L}$ was transferred in anode chamber and another $1 \mathrm{~L}$ in cathode. Anodic slot of MFC-R1 was then inoculated with E. coli (pure culture) at sterile conditions and complete set up was incubated $\left(37^{\circ} \mathrm{C}\right)$ for two days.

\section{Preparation of MFC Based on Anaerobic and Aerobic (Activated)} Sludge

MFC based on anaerobic and aerobic (activated) sludge was named as MFC-R2 and prepared by pouring $1 \mathrm{~L}$ of anaerobic (activated) sludge in anodic chamber and $1 \mathrm{~L}$ of aerobic (activated) sludge in cathodic chamber. Further the growth supplements like, $\mathrm{NaHCO}_{3}(4 \mathrm{~g}), \mathrm{NH}_{4} \mathrm{Cl}$ (0.62 g), $\mathrm{KCl}(0.26 \mathrm{~g}), \mathrm{NaHPO}_{4}(8.44 \mathrm{~g}), \mathrm{Na}_{2} \mathrm{HPO}_{4}(5.50 \mathrm{~g}),\left(\mathrm{NH}_{4}\right)_{2} \mathrm{SO}_{4}$ (1.02 g), $\mathrm{MgSO}_{4} .7 \mathrm{H}_{2} \mathrm{O}(0.4 \mathrm{~g}), \mathrm{CaCl}_{2}(0.03 \mathrm{~g}), \mathrm{FeCl}_{3} .6 \mathrm{H}_{2} \mathrm{O}(0.002 \mathrm{~g})$ and $\mathrm{MnSO}_{4} \cdot \mathrm{H}_{2} \mathrm{O}(0.04 \mathrm{~g})$ were dissolved in $100 \mathrm{~mL}$ distilled water. Half of this solution $(50 \mathrm{~mL})$ was added in anodic chamber and rest $(50 \mathrm{~mL})$ in cathode chamber and complete set up was incubated $\left(37^{\circ} \mathrm{C}\right)$ for two days.

\section{Working of MFCs (for both MFC-R1 and MFC-R2)}

After two days of incubation, $2 \mathrm{~g}$ of glucose (substrate) was supplemented in anode chamber and again incubated for an hour at $37^{\circ} \mathrm{C}$. The wires were then connected to millivolt meter. The generated electricity was measured and recorded as output voltage at every half an hour in millivolt $(\mathrm{mV})$. The complete set up of the MFCs constructed in working condition are showed in Figures 3 and 4.

\section{Results}

Here two different MFCs were constructed which differed in the nature of micro-organism employed for electricity generation. The first (MFC-R1) cell was made of pure culture of E.coli and MFC-R2 of varied bacterial culture (anaerobic activated sludge). The recorded voltage yield was compared at certain substrate (glucose) concentration. To achieve this, MFC-R1 was first operated with $2 \mathrm{~g}$ of glucose and voltage was recorded at every half-an-hour until it declined and reached to a minimum worth. A similar methodology was rehashed for MFC-R2.

\section{Electricity genesis by MFC-R1}

Potential difference across both electrodes $(-10 \mathrm{mV})$ was observed just after adding substrate (glucose). For the first $2 \mathrm{~h}$, voltage yield increased slowly and reached to a mark of $10 \mathrm{mV}$ toward the finish of $2^{\text {nd }} \mathrm{h}$ (Figure 5a). Further, voltage was increased exponentially for next 4 $\mathrm{h}$ and reached to a mark of $150 \mathrm{mV}$ toward the finish of $6^{\text {th }} \mathrm{h}$ which was the peak value of electricity generated by MFC-R1. In the $7^{\text {th }} \mathrm{h}$, output was stable at $150 \mathrm{mV}$ (Table 1and Figure 5a).

On next morning ( $24 \mathrm{~h}$ after adding of substrate), the voltage was reduced to $110 \mathrm{mV}$. After providing proper aeration in cathodic chamber, the voltage output was again increased and reached to $140 \mathrm{mV}$ toward the finish of $24^{\text {th }} \mathrm{h}$. The voltage was constant for $25^{\text {th }} \mathrm{h}$ and started decreasing gradually and finally reached at $110 \mathrm{mV}$ toward the finish of $28^{\text {th }} \mathrm{h}$. Moreover, the voltage started decreasing at greater pace and reached to 40 $\mathrm{mV}$ toward the finish of $31^{\text {st }} \mathrm{h}$ on Day 2 (Table 2). On $3^{\text {rd }}$ day morning (48 $\mathrm{h}$ after substrate addition) the power productivity was recorded as $10 \mathrm{mV}$, which gradually reduced to zero within an hour (Figure 5b).

\section{Electricity genesis by MFC-R2}

Potential distinction of $10 \mathrm{mV}$ was observed just after adding substrate (glucose). For the $1^{\text {st }} \mathrm{h}$, the voltage revenue was increased gradually and reached to $20 \mathrm{mV}$. After that, potential energy increased exponentially for next $4^{\text {th }} \mathrm{h}$ and reached to $330 \mathrm{mV}$, just prior to finish of $5^{\text {th }} \mathrm{h}$. Within half-an-hour the output were increased and reached at $350 \mathrm{mV}$ and was stable for an hour. After that minor rise in voltage $(360 \mathrm{mV})$ was observed towards the end of $7^{\text {th }} \mathrm{h}$ on Day 1 (Table 3 and Figure 6a).

On the next morning ( $24 \mathrm{~h}$ after substrate addition), the voltage was observed to be reduced to $250 \mathrm{mV}$. After providing appropriate aeration in cathode slot, the voltage again increased and reached to 380 $\mathrm{mV}$ within one and-a-half hour and was constant for few next hours as recorded. The voltage reached to its most extraordinary estimation of $400 \mathrm{mV}$ toward the finish of $27^{\text {th }} \mathrm{h}$. After that, there was a slight fluctuation in for next few hours and the voltage was constant at 380 $\mathrm{mV}$ toward the finish of $31^{\text {st }} \mathrm{h}$ on Day 2 (Table 4 , and Figure $6 \mathrm{~b}$ ).

On the third day morning ( $48 \mathrm{~h}$ after substrate addition), the voltage recorded was $320 \mathrm{mV}$, trailed by a slight increase $(350 \mathrm{mV})$ in the $49^{\text {th }} \mathrm{h}$. Thereafter, a steady drop in voltage was detected which became stable at $260 \mathrm{mV}$, Table 5 . On the fourth day morning (72 h after substrate addition), the output recorded was $250 \mathrm{mV}$ (Figure 6c), followed via slight increase $(270 \mathrm{mV})$ in the $73^{\text {rd }} \mathrm{h}$. After the $74^{\text {th }} \mathrm{h}$, a continuous decrease in the yield voltage was detected. The voltage declined steadily for following $2 \mathrm{~h}$, then came to $150 \mathrm{mV}$ toward the finish of $76^{\text {th }} \mathrm{h}$. There was steep voltage yield decline after $76^{\text {th }} \mathrm{h}$ to its minimum value of 50 $\mathrm{mV}$ toward the finish of $79^{\text {th }} \mathrm{h}$ on Day 4 (Table 6). Next day i.e. $5^{\text {th }}$ day morning ( $96 \mathrm{~h}$ after substrate addition), the output from cell was $10 \mathrm{mV}$ which gradually declined to zero within $60 \mathrm{~min}$ (Figure 6d).

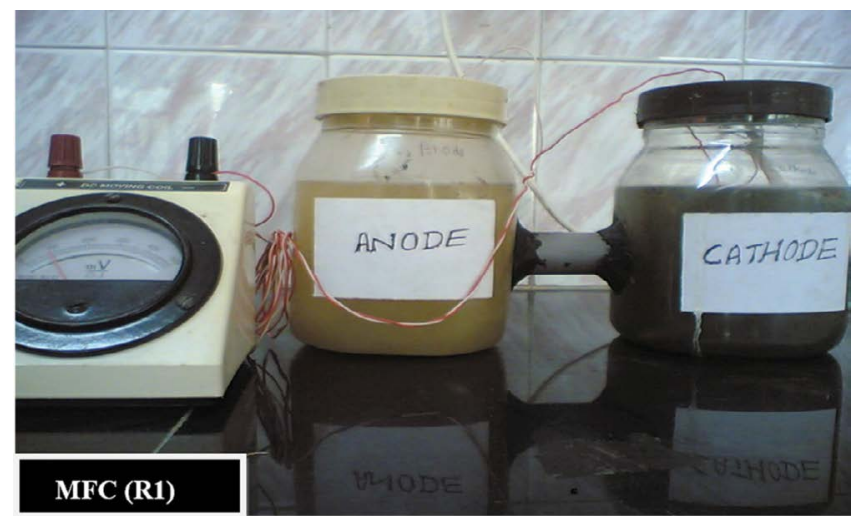

Figure 3: The complete setup of MFC-R1 in working condition.

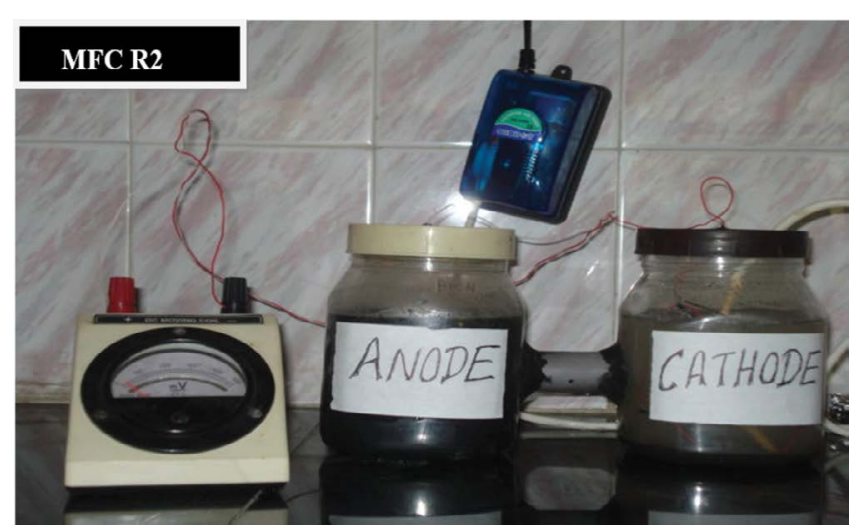

Figure 4: The complete setup of MFC-R2 in working condition. 


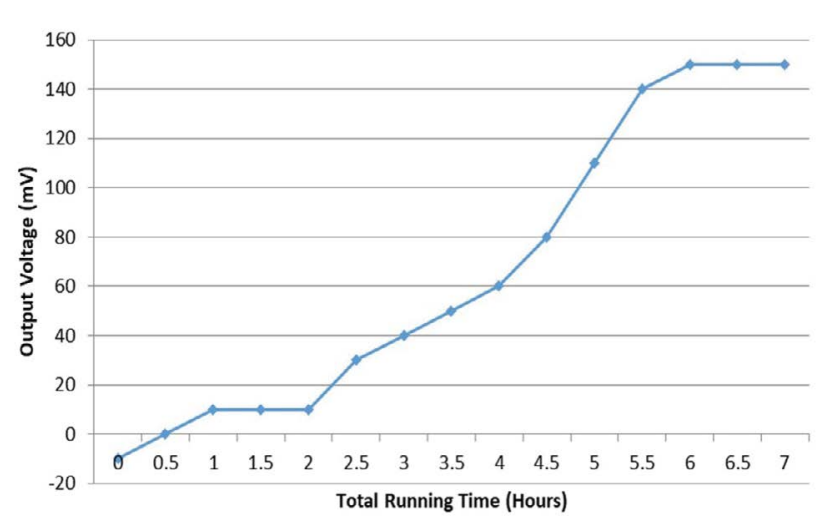

Figure 5a: Output voltage of MFC-R1 with respect to time (Day 1).

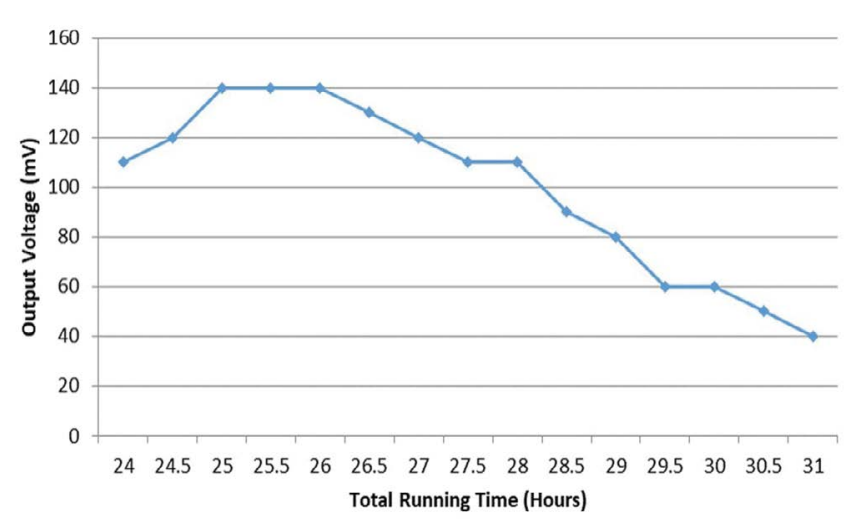

Figure 5b: Output voltage of MFC-R1 with respect to time (Day 2).

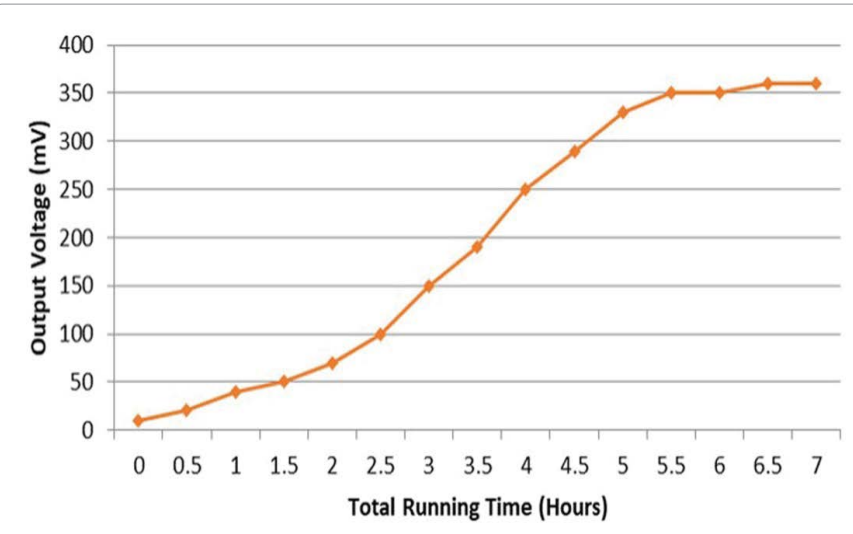

Figure 6a: Output voltage of MFC-R2 with respect to time (Day 1).

\section{Discussion}

Recently, prodigious attentions were waged for MFCs due to their insignificant functioning circumstances employing variable biodegradable substrates as fuel. The traditional MFC comprised of anode and cathode partitions but this research work is made through two chambered operated cell utilizing activated sludge and sugar as substrates. Other than the benefits of this innovation, despite

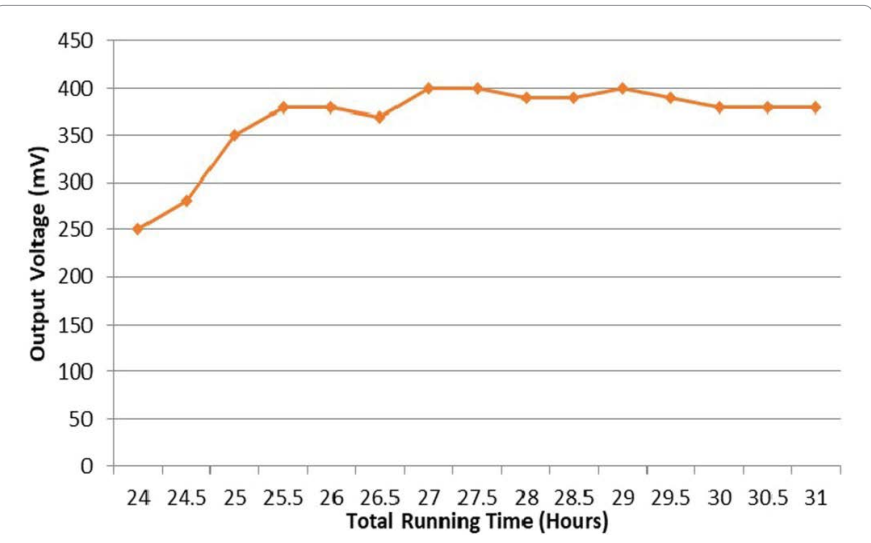

Figure 6b: Output voltage of MFC-R2 with respect to time (Day 2).

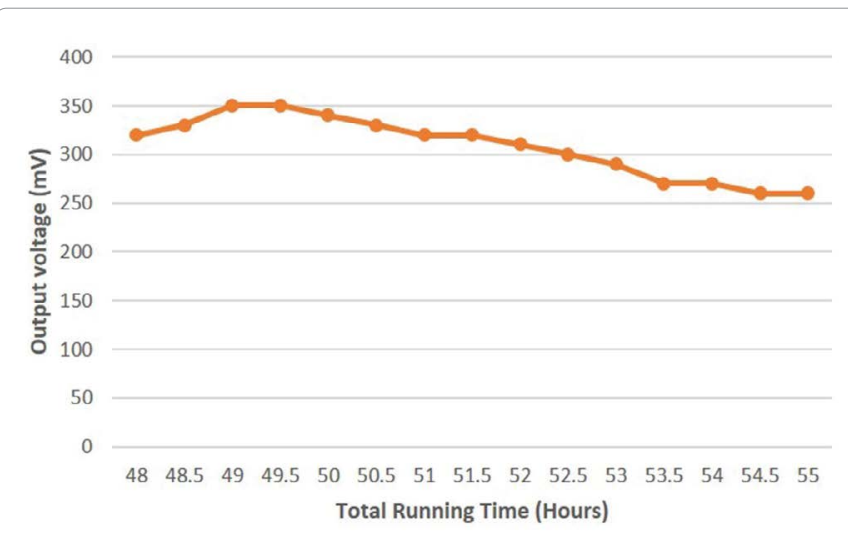

Figure 6c: Output voltage of MFC-R2 with respect to time (Day 3).

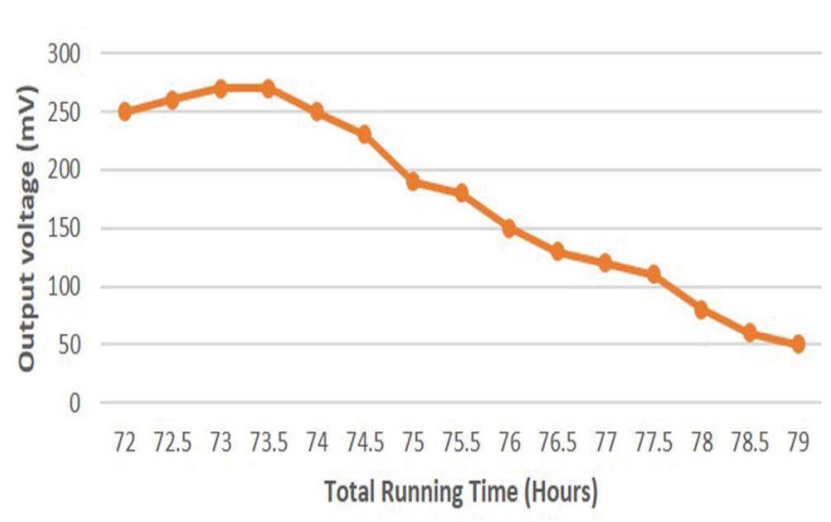

Figure 6d: Output voltage of MFC-R2 with respect to time (Day 4).

everything it faces viable obstructions, for example, small power and current density. Advance in configuration has given various angles that are to be researched to achieve a cell that may deliver huge and significant yields. Form the earlier reports and investigations I came to know about the obstructions and laggings in the voltage yield like, progressive yield were not being gained [23]. The maximum output was reported not above $235 \pm 1 \mu \mathrm{W}$ [24]. In present work different MFC 
Citation: Ankur B, Shipra S (2018) Microbial Fuel Cell: An Efficient Method to Utilize Prokaryotic Potential to Engender Reliable Energy. J Microb Biochem Technol 10: 69-75. doi: 10.4172/1948-5948.1000398

\begin{tabular}{|c|c|c|}
\hline $\begin{array}{c}\text { Time Duration For Day1 } \\
\text { (Hours) }\end{array}$ & $\begin{array}{c}\text { Total Running Time of } \\
\text { MFC R1 (Hours) }\end{array}$ & $\begin{array}{c}\text { Output Voltage } \\
\text { (mV) }\end{array}$ \\
\hline 0.0 & 0.0 & -10 \\
0.5 & 0.5 & 0 \\
1.0 & 1.0 & 10 \\
1.5 & 1.5 & 10 \\
2.0 & 2.0 & 10 \\
2.5 & 2.5 & 30 \\
3.0 & 3.0 & 40 \\
3.5 & 3.5 & 50 \\
4.0 & 4.0 & 60 \\
4.5 & 4.5 & 80 \\
5.0 & 5.0 & 110 \\
5.5 & 5.5 & 140 \\
6.0 & 6.0 & 150 \\
6.5 & 6.5 & 150 \\
7.0 & 7.0 & 150 \\
\hline
\end{tabular}

Table 1: Output voltage recorded with respect to time for MFC-R1 on Day 1.

\begin{tabular}{|c|c|c|}
\hline $\begin{array}{c}\text { Time Duration For Day2 } \\
\text { (hours) }\end{array}$ & $\begin{array}{c}\text { Total Running Time Of } \\
\text { MFC R1 (Hours) }\end{array}$ & $\begin{array}{c}\text { Output Voltage } \\
\text { (mV) }\end{array}$ \\
\hline 0.0 & 24.0 & 110 \\
0.5 & 24.5 & 120 \\
1.0 & 25.0 & 140 \\
1.5 & 25.5 & 140 \\
2.0 & 26.0 & 140 \\
2.5 & 26.5 & 130 \\
3.0 & 27.0 & 120 \\
3.5 & 27.5 & 110 \\
4.0 & 28.0 & 110 \\
4.5 & 28.5 & 90 \\
5.0 & 29.0 & 80 \\
5.5 & 29.5 & 60 \\
6.0 & 30.0 & 60 \\
6.5 & 30.5 & 50 \\
7.0 & 31.0 & 40 \\
\hline
\end{tabular}

Table 2: Output voltage generation in respect to time on Day 2 by MFC R1.

\begin{tabular}{|c|c|c|}
\hline $\begin{array}{c}\text { Time Duration for Day 1 } \\
\text { (Hours) }\end{array}$ & $\begin{array}{c}\text { Total Running Time of } \\
\text { MFC R2 (Hours) }\end{array}$ & $\begin{array}{c}\text { Output Voltage } \\
\text { (mV) }\end{array}$ \\
\hline 0.0 & 0.0 & 10 \\
0.5 & 0.5 & 20 \\
1.0 & 1.0 & 40 \\
1.5 & 1.5 & 50 \\
2.0 & 2.0 & 70 \\
2.5 & 2.5 & 100 \\
3.0 & 3.0 & 150 \\
3.5 & 3.5 & 190 \\
4.0 & 4.0 & 250 \\
4.5 & 4.5 & 290 \\
5.0 & 5.0 & 330 \\
5.5 & 5.5 & 350 \\
6.0 & 6.0 & 350 \\
6.5 & 6.5 & 360 \\
7.0 & 7.0 & 360 \\
\hline
\end{tabular}

Table 3: Voltage generation with respect to time on Day 1 by MFC R2.

\begin{tabular}{|c|c|c|}
\hline $\begin{array}{c}\text { Time Duration for Day 2 } \\
\text { (Hours) }\end{array}$ & $\begin{array}{c}\text { Total Running Time of } \\
\text { MFC R2 (Hours) }\end{array}$ & $\begin{array}{c}\text { Output Voltage } \\
\text { (mV) }\end{array}$ \\
\hline 0.0 & 24.0 & 250 \\
0.5 & 24.5 & 280 \\
1.0 & 25.0 & 350 \\
1.5 & 25.5 & 380 \\
2.0 & 26.0 & 380 \\
2.5 & 26.5 & 370 \\
3.0 & 27.0 & 400 \\
3.5 & 27.5 & 400 \\
4.0 & 28.0 & 390 \\
4.5 & 28.5 & 390 \\
5.0 & 29.0 & 400 \\
5.5 & 29.5 & 390 \\
6.0 & 30.0 & 380 \\
6.5 & 30.5 & 380 \\
7.0 & 31.0 & 380 \\
\hline
\end{tabular}

Table 4: Voltage generation with respect to time on Day 2 by MFC R2.

\begin{tabular}{|c|c|c|}
\hline $\begin{array}{c}\text { Time Duration for Day 3 } \\
\text { (Hours) }\end{array}$ & $\begin{array}{c}\text { Total Running Time of } \\
\text { MFC R2 (Hours) }\end{array}$ & $\begin{array}{c}\text { Output Voltage } \\
\text { (mV) }\end{array}$ \\
\hline 0.0 & 48.0 & 320 \\
0.5 & 48.5 & 330 \\
1.0 & 49.0 & 350 \\
1.5 & 49.5 & 350 \\
2.0 & 50.0 & 340 \\
2.5 & 50.5 & 330 \\
3.0 & 51.0 & 320 \\
3.5 & 51.5 & 320 \\
4.0 & 52.0 & 310 \\
4.5 & 52.5 & 300 \\
5.0 & 53.0 & 290 \\
5.5 & 53.5 & 270 \\
6.0 & 54.0 & 270 \\
6.5 & 54.5 & 260 \\
7.0 & 55.0 & 260 \\
\hline
\end{tabular}

Table 5: Voltage generation with respect to time on Day 3 by MFC R2.

\begin{tabular}{|c|c|c|}
\hline $\begin{array}{c}\text { Time Duration for Day 4 } \\
\text { (Hours) }\end{array}$ & $\begin{array}{c}\text { Total Running Time of } \\
\text { MFC R2 (Hours) }\end{array}$ & $\begin{array}{c}\text { Output Voltage } \\
\text { (mV) }\end{array}$ \\
\hline 0.0 & 72.0 & 250 \\
0.5 & 72.5 & 260 \\
1.0 & 73.0 & 270 \\
1.5 & 73.5 & 270 \\
2.0 & 74.0 & 250 \\
2.5 & 74.5 & 230 \\
3.0 & 75.0 & 190 \\
3.5 & 75.5 & 180 \\
4.0 & 76.0 & 150 \\
4.5 & 76.5 & 130 \\
5.0 & 77.0 & 120 \\
5.5 & 77.5 & 110 \\
6.0 & 78.0 & 80 \\
6.5 & 78.5 & 60 \\
7.0 & 79.0 & 50 \\
\hline
\end{tabular}

Table 6: Voltage generation with respect time on Day 4 by MFC R2.

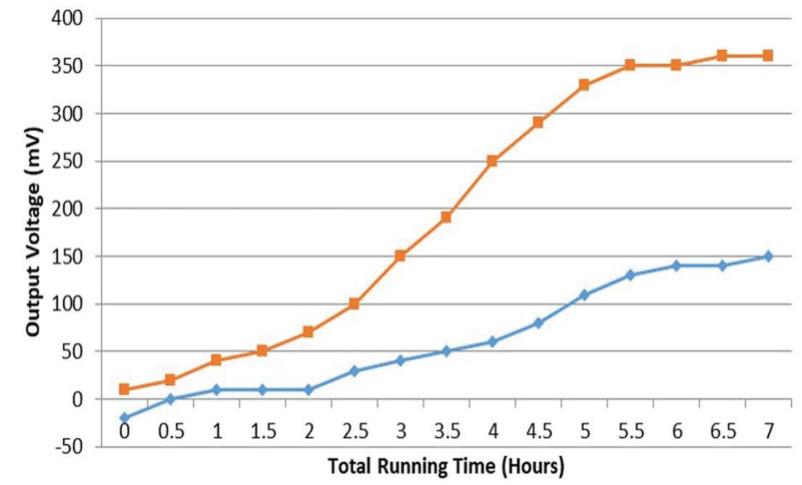

Figure 7a: Comparison of Output Voltage of MFC-R1 and MFC-R2 (Day 1).

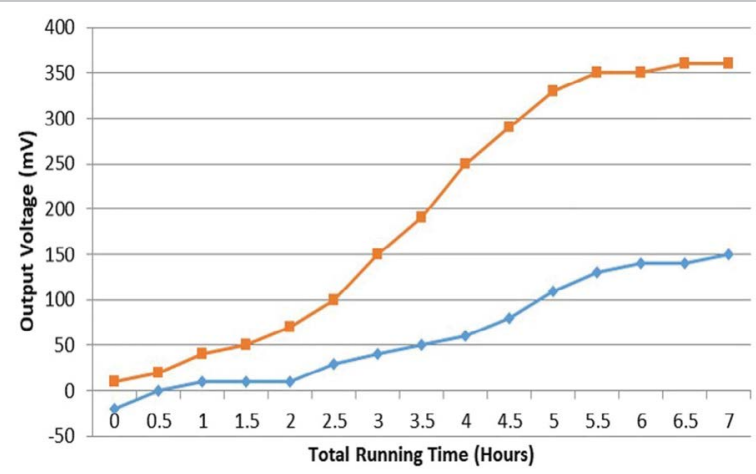

Figure 7b: Comparison of Output Voltage of MFC-R1 and MFC-R2 (Day 1). Comparison of Output Voltage of MFC-R1 and MFC-R2 (Day 2). 
portions (anode, cathode and salt bridge) have been designed manually to overcome suggested practical challenges and maximum voltage gain was recorded above $280 \mathrm{mV}$ (MFC-R2) which is much higher than the above said report. Microorganisms effectively catabolize substrate creating bioelectricity. MFCs are one of the utmost up to date innovations to deliver energy from various substrates as sources. In light of the guarantee of feasible vitality age from various substrates, for example, natural organic squanders, inquire about has been escalated over the most recent couple of years. As petroleum sources are being depleted, energy crisis encouraged researchers for considering alternative energy sources. Moreover, using fossil fuels might cause environmental pollution. Clean and green fuels, significantly fuel cells and biofuels, as new energy generating sources without any pollution are suitable replacements of old-style fossil fuels.

\section{Conclusion}

Initially in MFC-R1 voltage yield was negative due to difference in solution ionic magnitude or strength in both (anode and cathode) chambers. But the initial reading of MFC-R2 was positive and this may be because of additional free electrons available in anodic chamber. In lack of oxygen, free electrons were not used up and when the circuit was completed, they cascaded displaying positive deflection of $10 \mathrm{mV}$. The streaming of electrons from cathode to positive ions produced at anode happens to be through salt-bridge. The voltage of MFC-R1 increased with a slower pace compared to MFC-R2 and reached maximum to 150 $\mathrm{mV}$ while in MFC-R2, the current augmented at a greater pace and reached maximum of $400 \mathrm{mV}$.

In MFC-R2, the higher voltage sustained for long while in MFC-R1 it started decreasing after Day 1, because quantity of organisms in MFC-R2 was substantially higher (than in MFC-R1). Also, in MFC-R2, additional substrates (sludge rich in biomass/nutrients) were present and different microbes were grown-up under wild conditions (belonging to different genus/species/strains) to utilize that substrate. The dissimilarities in peak values of output voltage in both MFCs was due to presence of varied bacterial culture in MFC-R2, while in MFC-R1 only laboratory grown pure bacteria was present (E. coli) (Figure 7a).

For performance improvement in voltage yield in MFCs proper aeration (cathode chamber) is essential. It helps in proper mixing of $\mathrm{O}_{2}$ in the aerobic sludge and thus provides sufficient $\mathrm{O}_{2}$ as final electron acceptor. This has been proved in present investigation. In both the MFCs, when proper aeration was provided during the morning hours of $2^{\text {nd }}$ and $3^{\text {rd }}$ day (i.e., during the night time no aeration was given in cathode chamber), the voltage output was increased drastically (Figure $7 \mathrm{~b}$ ).

The voltage in MFC-R1 reached to its lowermost mark on the second day while in MFC-R2 voltage was sustained for four days. This was because, in MFC-R1, only $2 \mathrm{~g}$ of glucose (substrate) was present and once consumed completely, no substrate was available that may perhaps be consumed by the E. coli to produce electrons. While in MFC-R2, there was many substrates present, as the waste-water is highly biomass splendid. Moreover, the microorganism fledged in wild conditions might be much proficient in utilizing available substrates in the medium for their metabolic activities than the laboratory grown single culture of E. coli. The result depicts that MFC-R2 has given better voltage yield than MFC-R1.

In this project two dissimilar microbial cultures were used (i) pure laboratory culture of E. coli and (ii) Mixed or blended microbial culture obtained from sludge to produce electricity. The voltage produced using mixed or blended microbial culture was significantly higher and sustained for longer time than the voltage generated by E. coli. Power origination from utilized wastewater has imminent potential. MFCs have pulled in developing consideration for their capability of power manufacturing and simultaneously treating natural waste water. MFCs are being created for both waste-water treatment and for the age of biopower and the thought would be commercially practical.

\section{Acknowledgement}

The authors are thankful to Dr. Gajendra B. Singh and Er. Ankit Singh, Department of Biotechnology and Life-Sciences, Mangalayatan University for their suggestions in the preparation of research article.

\section{References}

1. Ardolino F, Parrillo F, Arena U (2018) Biowaste-to-biomethane or biowaste-toenergy? An LCA study on anaerobic digestion of organic waste. J Cleaner Prod 174: $462-476$.

2. Lemery J, Auerbach P (2017) Enviromedics: The impact of climate change on human Health: Rowman \& Littlefield. Lanham, Maryland, United States.

3. Indragandhi V, Subramaniyaswamy V, Logesh R (2017) Resources, configurations, and soft computing techniques for power management and control of PV/wind hybrid system. Renew Sustain Energy Rev 69: 129-143.

4. Kukreja S, Thakur K, Salaria N, Goutam U (2017) Changing trends in microalga energy production-review of conventional and emerging approaches. J Pure Appl Microbiol 11: 993-1008.

5. Rahimnejad M, Adhami A, Darvari S, Zirepour A, Oh SE (2015) Microbial fue cell as new technology for bioelectricity generation: a review. Alexandria Eng J 54: 745-756.

6. Sadhukhan J, Lloyd JR, Scott K, Premier GC, Eileen HY et al. (2016) A critica review of integration analysis of microbial electrosynthesis (MES) systems with waste biorefineries for the production of biofuel and chemical from reuse of $\mathrm{CO}_{2}$. Renew Sustain Energy Rev 56: 116-132.

7. Pandit S, Das D (2018) Microbial fuel cell: Principles of microbial fuel cell for the power generation: 21-41 Springer Berlin Germany.

8. Liu H, Grot S, Logan BE (2005) Electrochemically assisted microbial production of hydrogen from acetate. Environ sci technol 39: 4317-4320.

9. Aghababaie M, Farhadian M, Jeihanipour A, Biria D (2015) Effective factors on the performance of microbial fuel cells in wastewater treatment-A review. Environ Technol Rev 4: 71-89.

10. Rabaey K, Verstraete W (2005) Microbial fuel cells: Novel biotechnology for energy generation. Trends biotechnol 23: 291-298.

11. Ho S H, Nagarajan D, Ren N Q, Chang J S (2018) Waste biorefineriesintegrating anaerobic digestion and microalgae cultivation for bioenergy production. Curr opinion biotechnol 50: 101-110.

12. Li W W, Yu H Q, He Z (2014) Towards sustainable wastewater treatment by using microbial fuel cells-centered technologies. Energy Environ Sci 7: 911-924.

13. Liu H, Ramnarayanan R, Logan B E (2004) Production of electricity during wastewater treatment using a single chamber microbial fuel cell. Environ sci technol 38: 2281-2285.

14. Mousavi MP, Saba SA, Anderson EL, Hillmyer MA, Bühlmann P (2016) Avoiding errors in electrochemical measurements: Effect of frit material on the performance of reference electrodes with porous frit junctions. Analy chem 88 8706-8713.

15. Logan B E, Hamelers B, Rozendal R, Schröder U, Keller J, et al. (2006) Microbial fuel cells: methodology and technology. Environ sci technol 40: 51815192.

16. Liu H, Logan BE (2004) Electricity generation using an air-cathode single chamber microbial fuel cell in the presence and absence of a proton exchange membrane. Environ sci technol 38: 4040-4046.

17. Bond DR, Holmes DE, Tender LM, Lovley DR (2002) Electrode-reducing microorganisms that harvest energy from marine sediments. Sci 295: 483-485.

18. Chaudhuri S K, Lovley D R (2003) Electricity generation by direct oxidation of glucose in mediatorless microbial fuel cells. Nature biotechnol 21:1229. 
Citation: Ankur B, Shipra S (2018) Microbial Fuel Cell: An Efficient Method to Utilize Prokaryotic Potential to Engender Reliable Energy. J Microb Biochem Technol 10: 69-75. doi: 10.4172/1948-5948.1000398

19. Goswami R, Mishra V K (2018) A review of design, operational conditions and applications of microbial fuel cells. Biofuels 9: 203-220.

20. Wei J, Liang P, Huang $X(2011)$ Recent progress in electrodes for microbial fue cells. Biores technol 102: 9335-9344.

21. Sudarsan J, Prasana K, Nithiyanantham S, Renganathan K (2015) Comparative study of electricity production and treatment of different wastewater using microbial fuel cell (MFC). Environ Earth Sci 73: 2409-2413.
22. Guo K, Prévoteau A, Patil SA, Rabaey K (2015) Engineering electrodes for microbial electrocatalysis. Curr opinion biotechnol 33: 149-156.

23. Santoro C, Arbizzani C, Erable B, leropoulos I (2017) Microbial fuel cells: From fundamentals to applications-A review. J power sour 356: 225-244.

24. Kodali M, Herrera S, Kabir S, Serov A, Santoro C, et al. (2018) Enhancement of microbial fuel cell performance by introducing a nano-composite cathode catalyst. Electrochimica acta 265: 56-64 